\title{
Rules and rewards in the age of sail: a reply
}

\author{
Douglas W. Allen* \\ Department of Economics, Simon Fraser University, ${ }^{1} 8888$ University Drive, Burnaby, BC, \\ Canada V5A 1 S6
}

Received 3 January 2003

\section{Introduction}

Benjamin and Thornberg (hereafter BT) have written a comment on my paper analyzing the incentive structure of the British Navy. They contend that I have "misread the historical development of the Royal Navy, and missed crucial technological and institutional features that are essential to understanding the Navy's organization and success." This is a surprising statement given the fundamental agreement we have over the grounds for this navy's success during the age of sail. Their paper, however, is flawed in its interpretation of my paper. Incorrectly characterizing my argument, they have built a case against a straw man. Their comment amounts to a dispute over a few facts.

\section{Statements of agreement}

BT open their paper with the sentence: "Incentives matter." (p. 195). On this point we are in complete agreement. I argued in Allen (2002) that the key to the success of the British Navy during the age of sail was its reliance on a set of rules forcing captains to fight. These "no-excuse" rules worked at a time when excuses for failure were easy to come by, given the role of nature in propelling ships by wind. Other navies at the time generally did not adopt the rules of the British, and suffered the consequences. My paper explains why the rules were different for the army, the privaters, and why they all disappeared with the coming of steam.

\footnotetext{
${ }^{*}$ Fax: +604-291-5944.

E-mail address: allen@sfu.ca.

${ }^{1}$ Thanks to Clyde Reed and Eugene White for their comments.
} 


\section{BT conclude their paper with the following quote:}

How all of this [the success] was accomplished is a story with many pieces, but one of those pieces is surely this: the architects and commanders of the British Royal Navy understood that incentives matter. The Royal Navy adopted sophisticated organizational structures and compensation schemes that supplied its officers and men with incentives to exert greater effort than their foes - effort that produced consistent, enduring success.

[p. 209]

I could not have said it better myself. Unfortunately, in between the bookends of agreement, there is much to complain about.

\section{Lack of citation}

Although we are in broad agreement over key nautical and historical facts, BT fail to alert this to the reader by ignoring points made in my original article. In so doing they subtly and indirectly make the case for my lack of authority and build the case for their own authority. Consider the following quotes, the first from BT, the second from my original paper.

1. The Royal Navy was the most successful naval force in the world from the end of the 17 th to the early 20th century, success that cannot be explained by technology, resource endowments, or even luck.

[BT p. 195]

For over 150 years between 1670 and 1827 -virtually the entire age of fighting sail-the British Navy was successful in fighting the Spanish, Dutch, French, and a host of other smaller European countries. "... it would appear, if anything, that the British suffered a marginal technical disadvantage."

[Allen: pp. 204-205, 208]

2. What, then, can explain the line of battle as a fighting tactic? It starts with this: ships are longer than they are wide,... the line of battle formation... maximized the impact of these weapons.

[BT: p. 202]

Although it reduced the chance of masking another ships fire, and brought the full broadside to bear on the enemy, as mentioned above it restricted movements of ships when other strategies may have worked better.

[Allen p. 218] ${ }^{2}$

3. Rodger's conclusion is consistent with the well-known fact that British sailors in the age of sail had far more to fear from disease and accident than they did from the enemy.

\footnotetext{
${ }^{2}$ BT miss the essence of my argument over the line of battle. I acknowledge that the line allowed for a full broadside - the point they make - but I also point out that before the line was introduced there was widespread failure to engage in battle.
} 
[BT p. 200]

Indeed, a sailor in the British Navy was much more likely to die of disease or accident than from battle.

[Allen: p. 207]

4. On the strategic front, insular England had to control the sea or die; hence she chose aggression. In contrast, continental France, had merely to keep England distracted.

[BT: p. 204]

A continental power like France no doubt faced different constraints than its island neighbor when it came to directing efforts on land and at sea. For Britain, its Navy was its chief form of defense, while for France the Navy was primarily used to keep in touch with overseas possessions and to protect merchant trade - neither of which were as vital to France as they were for Britain.

[Allen: p. 229]

5. All of the authorities agree that patronage was essential to the promotion system of the Royal Navy.

[BT: p. 207]

The process of promotion to captain in the British Navy was complicated indeed. Perhaps the most important factor was patronage.

[Allen: p. 223]

6. But — and this is critical - they could hope to earn this only if they had command of a vessel. It was command that offered the promise of riches, not merely rank.

[BT: p. 208]

When a captain or admiral was not at sea they were on half-pay... While at sea, a captain made twice the wage and had the potential to earn spectacular profits through prizes. Although seniority on the captain's list played some role in choosing a captain for command, the British Navy was free to choose any captain on its list.

[Allen: pp. 214-215]

By not giving proper references, BT give the impression that I've missed several critical features.

\section{Misrepresentation of argument}

The BT paper also misrepresents points I make in the original paper. They distort my views on the prize system, the value of different prizes, efficiency wages, and the role of captain autonomy.

\subsection{The prize system: a good thing or not?}

BT interpret my argument to mean the prize system was a bad idea. According to them, I imply the British Navy would have been better off if they had never used the 
system. Although they cannot find a single instance where I make such a claim, they assert:

Allen sees the financial incentive system of the Royal Navy as an important impediment to its success, rather than a source of it.

[BT p. 195]

Financial incentives were the Royal Navy's solution, not (as Allen claims) its problem...

[BT p. 195]

...the compensation system within the British Navy was not-as Allen would have it-the problem; it was the solution.

[BT p. 210]

Before addressing what I actually did say, it should be pointed out that the prize system also existed for the armies of the day, and I have argued elsewhere that this prize system on land created generally compatible incentives for soldiers and their King. ${ }^{3}$ I view the prize system as the main motivating factor in the Navy as well. However, as I point out in several places, unlike on land, the prize system at sea had a drawback. This does not mean it was a failure, a mistake, or a problem. Most incentive schemes have costs, but they are used because the benefits either exceed the costs, or as in the case of the British Navy, schemes are found to mitigate the costs. I did say the following about the prize system.

The central compensation scheme in the British Navy was a wage arrangement that rewarded captains well if they were successful and remained at sea. This system revolved around the taking of prizes... the use of prizes in the navy was a two-edged sword - it motivated captains to be active at sea, but encouraged them, at the margin, to hunt for lucrative prizes instead of pursuing more strategic objectives. [footnote] I will not argue that use of prizes created a perverse incentive structure. On the contrary, it was an essential part of the incentive structure of all navies and armies of the time. Nor will I argue that actual combat was not lucrative in its own right. What I argue is that the payment by prizes in the navy had a drawback, namely that captains preferred the most valuable prizes net of the costs of capture. These prizes were not always the ones of most military value.

[Allen p. 206]

Never do I say that the prize system was a mistake or that the navies of the time would have been better without it. Ironically, at one point in their paper BT agree with me:

Thus, our point is not that captains were free of temptation, or that prize money from merchant ships was an inconsiderable source of income for them. What is unlikely is that there was a substantial bias toward pursuing merchantmen over enemy vessels of war, relative to the Crown's interest.

[BT p. 199]

The first sentence is simply the point I'm making. The second point confuses the incentive with the actual outcome, which I will address later.

\footnotetext{
${ }^{3}$ See Allen (1998).
} 


\subsection{The value of different prizes}

BT want to make the claim that I've missed the boat on the value of prizes. They see the truly valuable prizes as the enemy warships, and therefore do not see any incompatibility in incentives caused by the prize system. They make the following assertions of my opinion (they cannot find any direct quotes on this point).

In his view, there were two reasons for this: (i) merchantmen were more valuable prizes than were enemy warships...

[BT: p. 196]

Allen argues that enemy warships were high-cost, low return targets compared to merchantmen.

[BT p. 196]

Allen argues that the typical captain was prone to dereliction of duty in his drive to, in his words, 'seek after private fortune at the expense of the King'.

[BT: p. 197]

The central point of Allen's argument depends on the claim that the value of merchant ships as prizes exceeded that of enemy warships.

[BT: p. 198]

What did I actually say regarding the value of prizes?

Most naval officers no doubt had a tremendous sense of duty and were well aware of the prizes, promotions, and job security that could result from a successful military victory. However, at the margin... a captain could avoid bloody battles and enrich himself at the same time.

[Allen: p. 211, emphasis added]

An added advantage of capturing an enemy naval ship was the building of a reputation which would be rewarded with future lucrative ships and stations.

[Allen p. 211]

All of these factors lowered the net value to a captain of engaging an enemy naval ships. An extreme example is the case of pirate ships. The value of the ships was generally low, they carried no cargo, and pirates would fight to the death to avoid capture. As a result, captains did not go out of their way to fight pirates. At the margin, a captain would be tempted to go after a merchant ship that does not fight back and might be loaded with a very valuable cargo.

[Allen: p. 211, emphasis added]

The point I make is that the net value of the prize is what mattered. I did not argue that warships were low valued or necessarily had a low return. I argued they were high valued, high cost prizes. I argued that at the margin there was an incentive to go after merchant ships, and that this incentive was incompatible with the interests of the Crown. BT make this point as their own: "The relevant question is the expected prize money of alternative vessels, net of the risks." (p. 199, emphasis in the original). 


\subsection{Efficiency wages}

In my original paper I argue the British Navy used efficiency wages as a discipline device. By offering an income profile with potentially large payoffs, the navy created an excess supply of captains. Any captain could be punished by being placed on halfpay awaiting a command that might never come. ${ }^{4}$ BT claim that "From our reading of Allen it is unclear whether he is referring to: (i) monthly wages or (ii) prize money when he uses the term 'efficiency wages'." This statement appears to provide a dilemma for me. Had I been referring to monthly wages I must be wrong, since these were not very high. On the other hand, "surely Allen cannot be arguing [that prize money was the efficiency wage] because the central thrust of most of his paper is that prize money was the source of the shirking that the Admiralty had to work so hard to overcome." Again BT confuse incentives with outcomes here, but ignoring this, do they represent my position on efficiency wages correctly? I state:

The cornerstone of the British Navy's organizational incentives was its method of remuneration. Compensation for captains and admirals was a combination of wages and prize money.

[Allen, p. 213]

Again, this could not be clearer, especially since I continue for two pages to explain the shares, the prizes, and the effects of not having to pay for the commission as was done in the army. Clearly I'm talking about the entire income package. The key piece of evidence for the efficiency wage was an excess supply of captains. BT later point out that Wareham (2001, p. 21) estimates that approximately $30 \%$ of all men promoted to post captain during the Napoleonic wars never received a vessel to command. Moreover, many of those post captains who commanded a vessel at some point spent only a matter of months in command." (p. 208).

\subsection{Captain autonomy}

In one of the few quotes from my paper BT note that I say: "In the areas of recruitment, promotion, retirement, and general control of officers... [there was] individual captain autonomy." What I actually said was:

In the areas of recruitment, promotion, retirement, and general control of officers, the Admiralty eventually replaced the system of individual captain autonomy. Whereas in the age of sail the Admiralty often had only veto power on promotions, by the second half of the 19th century they had complete control.

[Allen, p. 227]

Here I was briefly discussing the effect of introducing steam power on the general structure of the navy. I was talking about the "system" of captain autonomy, and from the context of the entire paper, it is clear that I did not mean that an individual captain was a law unto himself. In fact, on p. 225 I state "an important element in

\footnotetext{
${ }^{4}$ An efficiency wage is not necessarily a performance bond as BT claim, unless one wants to hold a very loose interpretation of bond.
} 
promotion was the recommendation from one's captain." (emphasis added). By eliminating critical words, and taking a passage out of context BT change the meaning of what I was saying.

\title{
5. Confusion over incentives and outcomes
}

\subsection{Little cheating... in equilibrium}

BT appear confused over the incentive of the prize system and the actual behavior resulting from all of the institutional structure of the navy. For example, they argue that the incentive to shirk must not have existed or been strong because most captains acted according to their duty. They cite Rodger on p. 199 to back this up, and claim that this is "contrary to Allen's claims." (p. 200). However, I point this out as the fundamental puzzle of the British Navy. In spite of the drawback of the prize system, the large role of nature, etc., the navy was successful. I state:

\begin{abstract}
As much as these temptations were present, the equilibrium amount of cowardice and private wealth accumulation appears low. ... So here remains the puzzle: although there were examples of cowardice and cheating, overall the British Navy fought well relative to its opponents for a long period of time, with no distinctive advantage in technology — what set of rules allowed this?
\end{abstract}

[Allen p. 212]

My point was that the British Navy, in response to the transaction cost problems of the time, devised a clever set of rules that mitigated the problem. The fact that in equilibrium there was less than ubiquitous cheating does not mean the incentive to cheat was not there, it only means the navy was successful in constraining it.

\subsection{Small chance of dying}

BT spend a great deal of time attempting to estimate the probability of a captain dying in command. They come up with some pretty small numbers. Again, this seems to miss the point. It must be kept in mind that there were only six major fleet encounters throughout the entire 18th century. Though there were many ship-to-ship battles, as BT note, these could end quickly if the odds were too one sided. The real question is, ex ante, before the heat of a battle and not knowing how many battles would occur, what were captains thinking? My only point is that he was aware of the fact that his life was in jeopardy. If in equilibrium, few captains died on the British side (at least much fewer than on the side of the opponent) then again, this is evidence of a system that worked well in spite of the incentive to preserve one's life. ${ }^{5}$

\footnotetext{
${ }^{5}$ In this section BT note "many battles were fought at distances (120-150 yards or more) at which short-range, smooth-bore small arms were largely or totally ineffective." True enough, the musket was inaccurate at this range. Though I mention the possibility of a captain being killed by a sniper, BT's commission of death by cannon fire at a distance of 120 yards implies I only referred to death by musket fire.
} 


\section{Disputes over factual matters}

There are points made in the BT comment that are simply disputes over factual matters or differences of opinion on issues where many historians disagree. On several of these points we just do not know the answer and must use reasonable judgment. These include: did Nelson actually fight in a line, was the smoke so blinding in a fleet battle that admirals could not tell if ships were engaged or not, was the weather gage an advantage or disadvantage in fighting, and to what extent did lieutenants watch their captains on behalf of the navy.

Let me briefly address these points. The issues of Nelson's tactics and smoke in battle are ones of monitoring. Nelson seldom fought in a conventional straight line formation. In each of his major battles his tactics varied, and the question of whether or not he fought in a line is debated among historians and the issue critically comes down to the definition of "a line." It is enough for me that historians Tunstall, Tracy, and Palmer all agree that Nelson fought in a line. The issue is a minor point for the argument of the paper because with the formation he used he could still tell who was engaged and who was not. BT also claim that the line could not be used as a monitoring device because the blinding smoke from the cannons would prevent visual inspection. They also point out that the line might stretch beyond the horizon and so visual contact would be impossible. On this point two things must be remembered. First, ships communicated with each other by flag signals. If the smoke was thin enough to see small flags, it should have been thin enough to see large ships. Second, though ships might be spread in a line past the horizon, as mentioned in my paper, the line contained van and rear admirals spread throughout. For large battles there could have been many admirals involved, and all ships would have been visible to at least one admiral.

One of the unique British rules I point to in my paper was the insistence to use the weather gage in battle; that is, to be up wind. In my reading of the historical literature on this point, there was almost universal consensus at the time that this was a tactical error. I point out it was an error only if one ignored the incentive issues. BT raise an interesting suggestion that having the weather gage allowed gravity to assist in getting the cannon back in place. Whether this was an advantage or not I do not know, but it would have to be traded off against problems gravity would have caused in the actual reloading of the cannon, since the cannon would have to be prevented from rolling back before the ball and charge could be put in place. Still this minor advantage would pale to having potentially half of one's fire power eliminated if the bottom row of guns could not be used in rough seas. BT also point out that the weather gage had the added advantage of "sailing downwind to engage the enemy at will." (p. 204). BT seem to forget that it takes two to engage. The leeward enemy, if not willing to fight, simply had to sail downwind away from the pending fight. Thus, the weather gage did not give the British unilateral control over the time of the battle.

As for lieutenants watching their captains, as stated in the paper, lieutenants were required to submit their journals to the Admiralty. If logs were kept only for training purposes, there would be no need for this. BT cite Lavery who states that "His captain could not help him [the lieutenant]; captains and commanders could only be 
made by commanders-in-chief on foreign stations, or by the Admiralty itself." Lieutenants had to fear their captains, but it was not an all consuming fear. The ultimate source for promotion came from other people in the administration, fleet, and Admiralty. The fact that captains would inspect the journal no doubt provided more honesty than lies, and frictions between the captain and lieutenants often developed over records kept on board, as in the infamous case of the Bounty. Last, it must not be forgotten that the master also kept a log to be returned to the Admiralty, and this would have policed both the captain and lieutenant as well. Ironically BT again seem to generally agree with what I say:

It is surely true that lieutenants did, as a matter of regulation, keep a journal during the commission, and did, if the necessity arose, perform the other two functions mentioned by Allen.

[BT: p. 205].

\section{Conclusion}

In the end, what are we left with? BT's comment, boils down to mostly agreement and minor differences of opinion. As I stated in my original paper, the work of BT "complements this one with an analysis of the warrant officers on board." Their argument that tournaments existed on board ship and possibly among captains is a good one, and in no way means that the other methods of generating performance I draw on are wrong. It is unfortunate they do not reciprocate these sentiments and choose instead to misrepresent my case. BT suggest that their paper is an "opening salvo," but in reality theirs is more of a misfire.

\section{References}

Allen, D., 1998. Compatible incentives and the purchase of military commissions. Journal of Legal Studies.

Allen, D., 2002. The British Navy rules: monitoring and incompatible incentives in the age of fighting sail. Explorations in Economic History 39, 204-231.

Benjamin, D., Thornberg, C., 2002. Rules, monitoring, and incentives in the age of sail. Explorations in Economic History 40, 195-211

Wareham, T., 2001. The Star Captains: Frigate Command in the Napoleonic Wars. Naval Institute, Annapolis, MD. 